\title{
about our members
}

Bert Bolin, chairman of the Intergovernmental Panel on Climate Change (IPCC), will be the keynote speaker at "Sustainable Development and Global Climate Change: Conflicts and Connections," a conference sponsored by the Center for Environmental Information. The conference will be held 4-5 December 1995 at the Doubletree Hotel, in Arlington, Virginia.

Bolin will present the findings of the IPCC's 1995 scientific assessment, due to be released shortly before the conference.

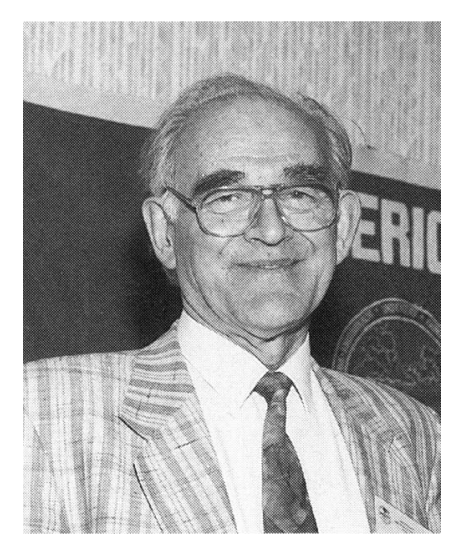

Bert Bolin
Bolin earned his B.S. in mathematics and physics from the University of Uppsala in 1946 and his Ph.D from the International Meteorological Institute in 1956. At the International Meteorological Institute he studied dynamic meteorology and numerical weather prediction. Upon the death of Carl-Gustaf Rossby in 1957, Bolin assumed temporary leadership of the institute and in 1961 was named the permanent chair of meteorology at the University of Stockholm. In 1965 he was asked by the European Space Research Organization to serve as the scientific director in Paris.

Involved with the Global Atmospheric Research Program from the beginning, Bolin served as the first chairman of the World Meteorological Organization/ ICSU Joint Organizing Committee from 1969 to 1971. He continued to served as a committee member until 1977. He was also the chairman of the proposal committee for the International Geosphere-Biosphere Programme (IGBP). He served as a member of the IGBP steering committee for several years.

He has been honored with several awards, including the International Meteorological Organization Prize in 1981, the AMS's Rossby Research Medal in 1984, the John and Alice Tyler Prize from the University of Southern California in 1988, and the Celsius Medal from the Royal Society of Sciences.

A Fellow of AMS, Berlin was elected an Honorary Member in 1993. He is a member of the Royal Swedish Academy of Sciences, the Royal Swedish Academy of Engineering, and the Advisory Norwegian Academy of Science.

The Sustainable Development and Global Climate
Change: Conflicts and Connections Conference will assess the linkages and the conflicts between sustainable development strategies and emerging findings about impacts, adaptation, and mitigation of global climate change effects.

Tom Potter, director of the Western Region of the National Weather Service, visited University Park on 8 September to be honored as an Alumni Fellow of the College of Earth and Mineral Sciences at the college's annual Obelisk Dinner. He received his doctorate in meteorology from The Pennsylvania State University (Penn State) in 1962.

The Alumni Fellow Award, sponsored by the Penn State Alumni Association and administered in cooperation with the colleges, is the most prestigious of the association's awards. The Board of Trustees has designated the title of Alumni Fellow as permanent and lifelong.

Potter has directed the western operation of the NWS since 1989. He was previously with the World Meteorological Organization in Geneva, Switzerland, where he directed the World Climate Programme, and then the World Weather Programme.

He received his undergraduate education in meteorology and mathematics at the University of Washington and joined the U.S. Air Force as a weatherman during the Korean War. He stayed in the air force for 24 years and rose to become head of the armed forces' worldwide weather organization, providing environmental and weather services to both the air force and army. During his military service, he also attended Penn State and the Industrial College of the Armed Forces and graduated from the Advanced Management Program at Harvard Business School.

On his retirement from the air force, Potter initially joined the faculty of St. Louis University but soon left to become director of the National Climatic Data Center of the National Oceanic and Atmospheric Administration (NOAA) in Asheville. From 1977 to 1982 he served as director of NOAA's Environmental Data and Information Service in Washington, D.C.

Potter is a Fellow of AMS and holds the Legion of Merit from the U.S. Air Force and the Presidential Award of Meritorious Executive in the Senior Executive Service.

During his Penn State visit, Potter was hosted by the Department of Meteorology and met undergraduate and graduate students in meteorology to discuss recent changes at NWS and professional career opportunities. 
Ask Norman Sissenwine of West Yarmouth, Massachusetts, about dealing with red tape and he will relate, in good humor, his 43-year experience with it. On 10 April 1952 the surgeon general of the Eighth Army recommended that Capt. Sissenwine receive the Bronze Star for meritorious service. After a four decade wait, he finally received the medal on 28 August 1995.

Sissenwine received the Bronze Star for his contributions to the Cold Injury Research Team during the Korean War. He was assigned to assess, establish, and supply weather stations in each U.S. battalion and regiment in Korea during 1951-52. Sissenwine's weather station program allowed servicemen and commanders to correlate the number, degree of cold injuries, and clothing with ambient temperatures during Korea's extreme weather occurrences.

It's fairly easy to figure how the medal was lost in the administrative tangle. Sissenwine contributed his meteorological expertise to the Army Air Corps during World War II. After the Allied victory, he served in the army reserves. In 1947 the air force became its own military branch and Sissenwine's records were transferred from the army to the air force. To help the Cold Injury Research Team, he was recalled to active duty in the army. Sissenwine said that the delay in receiving the medal was probably due to the fact that his military records were with the air force and the commendation came from the army.

U.S. Rep. Gerry Studds (Mass.) and his staff weeded through the red tape that delayed the presentation of the award. Along with the medal, Sissenwine received a belated thank you from the air force and a congratulatory letter from Studds.

AMS Past-President Earl G. Droessler has been honored by the establishment of a permanently en-

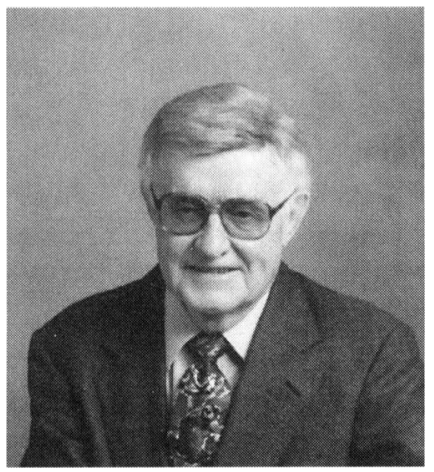
dowed scholarship in his name by the Mathematics Department of Loras College, Debuque, lowa. Each year a cash award will be given to a senior student mathematics major who has achieved excellence in his or her college studies.

Droessler is now serving as professor Earl G. Droessler emeritus at the State University of North Carolina in Raleigh, North Carolina. Loras College is his undergraduate alma mater where he earned an A.B. in mathematics.
Climatronics Corporation, headquartered in Bohemia, New York, has released the new Remtech RASS (Radio Acoustic Sounding System) for remote sensing of wind and air temperature.

Applying a simple principle of physics-the relationship of the speed of sound and air temperature-the RASS measures the temperature profile of the atmosphere.

The RASS can serve as a replacement for costly and labor intensive tethered balloons and radiosondes and when combined with a SODAR can be used instead of multilevel tall towers.

Applications include inversion detection, airport for forecasting, pollution dispersion, and radio wave propagation.

Climatronics has also developed a compact Sonic Weather Station. Featuring a no-moving-parts, twoaxis ultrasonic wind sensor, the compact weather station measures wind speed, direction, temperature, and relative humidity. Available in several configurations, options include an internal compass for self-alignment of wind direction, heaters for ice-free operation, immersible units, and additional sensors.

" AIZ MFCulok"
- VIS Part Number: $1392-520$
- NOAA/National Weather Service
NSN: 6660-01-103-9121
- Frequency channel: $1680 \mathrm{MHz}$
- Transmission range: -90'-50 ${ }^{\circ} \mathrm{C}, 10 \%-100 \%$
- Prebasedlined temperature and humidity sensors
- Pressure transducer
- New in original VIZ pack, complete with battery
- Quantity discounts
ALSO: SPARES FOR RADARS-RAWIN SETS-
SUPPORT EQUIPMENT
MARKARIAN BROS. \& ASSOCIATES
P.O. Box 11787
Fresno, California 93775 U.S.A.
(209) 868-3548
FAX: (209) 486-3050

